\title{
Uric Acid
}

\section{CHARACTERIZATION OF ITS INTERACTION}

\section{WITH HUMAN SERUM ALBUMIN}

\author{
Davio S. Campion, Rodney Bluestone, and James R. Kuinenberg \\ From the Department of Medicine, UCLA School of Medicine, Los Angeles, \\ California 90024, Wadsworth Veterans Administration Hospital, Los Angeles, \\ California 90073, and the Divisions of Medicine, Cedars-Sinai Medical Center, \\ Los Angeles, California 90029
}

\begin{abstract}
A B S T R A C T Binding of sodium urate to human serum albumin (HSA) was measured by continuous ultrafiltration at $\mathrm{pH} 7.4$ and ionic strength 0.16 over the concentration range $1-13 \mathrm{mg} / 100 \mathrm{ml}$. The percent sodium urate bound to $5 \mathrm{~g} / 100 \mathrm{ml} \mathrm{HSA}$ was constant over this concentration range: $30.3(\mathrm{SE} \pm 0.6) \%$ being bound at $4^{\circ} \mathrm{C}, 22.6 \pm 0.3 \%$ at $22.5^{\circ} \mathrm{C}$, and $19.6 \pm 0.3 \%$ at $37^{\circ} \mathrm{C}$. Derived association constants, assuming one binding site were $6.0 \times 10^{2} \mathrm{M}^{-1}\left(4^{\circ} \mathrm{C}\right), 4.47 \times 10^{2} \mathrm{M}^{-1}\left(22.5^{\circ} \mathrm{C}\right)$, and $3.88 \times 10^{2} \mathrm{M}^{-1}\left(37^{\circ} \mathrm{C}\right)$.
\end{abstract}

\section{INTRODUCTION}

Previous attempts to detect and measure urate binding to plasma proteins have involved one of several methods. These have included gel filtration, ultrafiltration in tubes, and equilibrium dialysis (1-3). However, the experimental methods were difficult to reproduce and failed to allow conventional analysis of binding characteristics. It appeared that the weakness of the urate-protein interaction, together with the tendency for bacterial degradation of urate to occur at room temperature, were important factors mitigating against the conventional approach to the problem. Recently, a reproducible equilibrium dialysis method for measuring urate binding was described (4). However, optimal binding was only achieved at $4^{\circ} \mathrm{C}$ in low-molarity buffer. It could be argued that in vitro binding under such unphysiologic conditions bears little relevance to the in vivo handling of plasma urate.

To have significance, the binding of urate must therefore be examined under the physiological conditions of

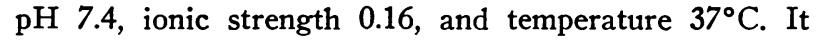
is also desirable to determine the extent of binding over the concentration range usually encountered clinically,

Received for publication 13 March 1973 and revised form 8 June 1973.
$3.0-12.0 \mathrm{mg} / 100 \mathrm{ml}$. As there has been considerable controversy as to whether urate is bound at all under these conditions, we have in this study simply measured the binding of sodium urate, the form in which uric acid ( $\mathrm{pK}, 5.4$ ) is presumably largely present in plasma, to defatted human serum albumin (HSA). Without competition for binding sites from fatty acids, we can then study the basic reaction and by varying the temperature establish thermodynamic data for the interaction. Without such data, interpretation of the effects of fatty acids or displacement by competitive-binding drugs is not possible.

\section{METHODS}

Fractional binding of sodium urate was determined with an Amicon Ultrafiltration Cell (Amicon Corp., Lexington, Mass.) and by the continuous ultrafiltration technique of Blatt, Robinson, and Bixler (5). A 50-ml ultrafiltration cell with PM 10 Amicon membrane was connected via a 1-liter reservoir to a nitrogen gas cylinder. $\mathrm{A} \mathrm{pH} 7.4$ phosphate buffer solution of calculated ionic strength 0.16 was used for all experiments. Binding was determined by two separate runs of continuous ultrafiltration, the cell contents being constantly mixed by a magnetic stirrer. The ultrafiltration chamber in the first run contained $50.0 \mathrm{ml}$ of buffer and in the second, $50.0 \mathrm{ml}$ of $5 \mathrm{~g} / 100 \mathrm{ml}$ defatted HSA (crystalline human serum albumin, electrophoretically pure, Calbiochem, San Diego, Calif.). For both runs, the reservoir contained a solution of sodium urate in phosphate buffer at exactly $15.0 \mathrm{mg} / 100 \mathrm{ml}\left(789 \times 10^{-6} \mathrm{M}\right)$. After pressurization of the chamber and tubing, ultrafiltration was carried out at $10 \mathrm{lbs} /$ in $^{2}$. and ultrafiltrate collected into previously dried and weighed test tubes. Ultrafiltration was continued until at least $70 \mathrm{ml}$ of ultrafiltrate, collected in $2-4 \mathrm{ml}$ volumes, had formed. This allowed the binding of urate to be studied over the concentration range of $1.0-13 \mathrm{mg} / 100 \mathrm{ml}$. At the end of the experiment, the volume in the chamber was again measured, as occasionally a continuous small leak of nitrogen caused a $1-2.0 \mathrm{ml}$ increase in volume of the chamber during

${ }^{1}$ Abbreviations used in this paper: BSA, bovine serum albumin; HSA, human serum albumin; $\mathrm{P}$, serum protein. 
the experiment. If this occurred, adequate corrections were made in the calculations. The volume of ultrafiltrate collected in each tube was determined by weight to four decimal places (with correction for temperature).

Calculations. Let $v_{i}$ be volume in liters of $i^{\text {th }}$ ultrafiltrate collected, $V$ be volume of solvent in chamber in liters, $(R)$ be sodium urate concentration in the reservoir, and $(M)$, be sodium urate concentration in $i^{\text {th }}$ collection. As this is a closed system the volume of solution entering the chamber in the $i^{\text {th }}$ period exactly equals the volume leaving $\left(v_{i}\right)$. Therefore:

$$
\begin{aligned}
\text { moles into chamber } & =v_{i}(R), \\
\text { moles out of chamber } & =v_{i}(M)_{i}, \\
\text { and moles retained } & =v_{i}(R)-v_{i}(M)_{i} .
\end{aligned}
$$

At the end of the $i^{\text {th }}$ period, the increase in total concentration in chamber during the $i^{\text {th }}$ period

$$
=\frac{1}{V}\left(v_{i}(R)-v_{i}(M)_{i}\right)
$$

At the end of the $n^{\text {th }}$ period, total moles per liter in chamber

$$
=\frac{1}{V} \sum_{i=i}^{n}\left(v_{i}(R)-v_{i}(M)_{i}\right)
$$

During the $n^{\text {th }}$ period, the urate concentration in the ultrafiltrate collected

$$
=\text { moles per liter free in chamber }=\left(M_{n}\right)
$$

Then moles per liter bound in chamber

$$
=\frac{1}{V} \sum_{i=i}^{n}\left(v_{i}(R)-v_{i}(M)_{i}\right)-\left(M_{n}\right)
$$

In essence a series of separate ultrafiltration experiments at a constant albumin concentration but increasing concentrations of sodium urate is performed in sequence. But in each section the concentration of total, free, and bound urate can be precisely calculated or experimentally determined. As the concentration of urate in the reservoir and the albumin in the chamber, and the collection volume $\left(v_{i}\right)$ can be accurately determined, the only limit on accuracy in this technique is urate analysis. By using autoclaved buffer solutions, sterilized chambers and tubing, and weighing and freezing of ultrafiltration samples immediately after collection, bacterial degradation of urate was completely avoided. Urate determination was performed using the method of Liddle, Seegmiller, and Laster (6).

\section{RESULTS}

At all times, with buffer alone in the ultrafiltration chamber, the concentration of urate in the ultrafiltrate was equal to the calculated (Eq. 5) total urate concentration of the chamber, and at the end of each such run the measured urate in the last ultrafiltrate fraction collected equaled the measured total urate in the chamber, with less than $2 \%$ error. There was, therefore, no binding of urate to the membrane and no reflection of urate from the membrane. That equilibrium of urate with albumin-urate complex was established within the time of sample collection was demonstrated by ultrafiltration of an albumin solution immediately after the addition of urate. Three consecutive $1.0-\mathrm{ml}$ samples of ultrafiltrate were then collected and, as the urate concentration in each sample was identical, equilibrium must have been established within the time of collection of the first sample. This is in accord with the conceptual model of

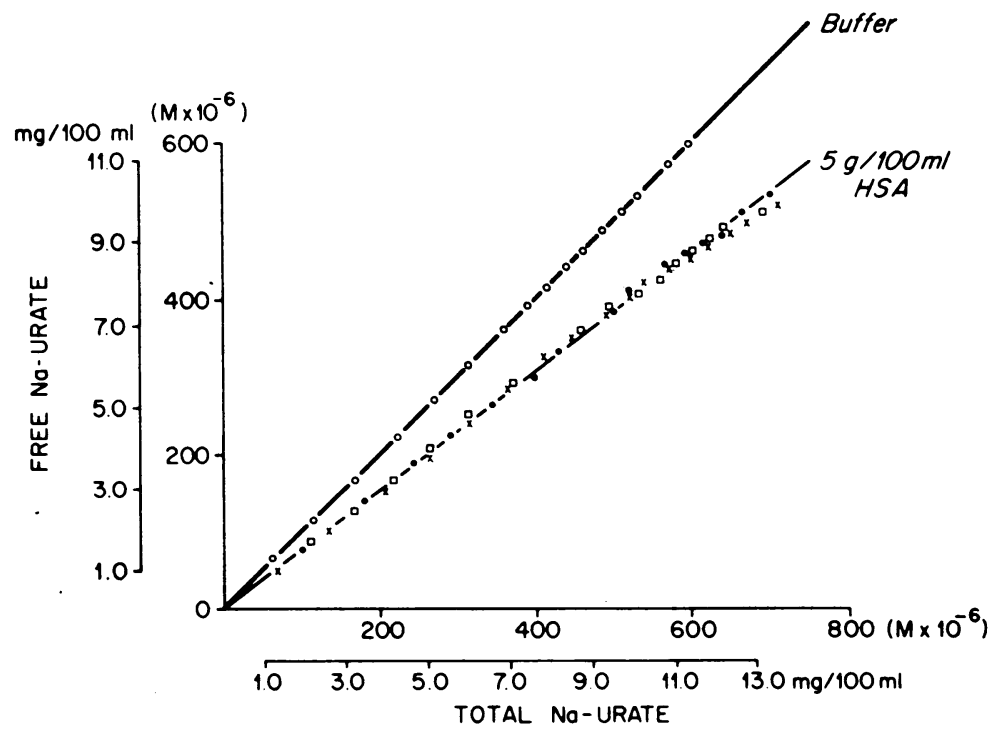

FIgURE 1 Binding of $\mathrm{Na}$-urate by $5 \mathrm{~g} / 100 \mathrm{ml} \mathrm{HSA}$ at $\mathrm{pH} 7.4$, ionic strength $0.16,22.5^{\circ} \mathrm{C}$. $\bigcirc-\bigcirc$, phosphate buffer; $-\square, \times-\times, \square-\square$, three separate experiments with $5 \mathrm{~g} / 100 \mathrm{ml}$ albumin. 


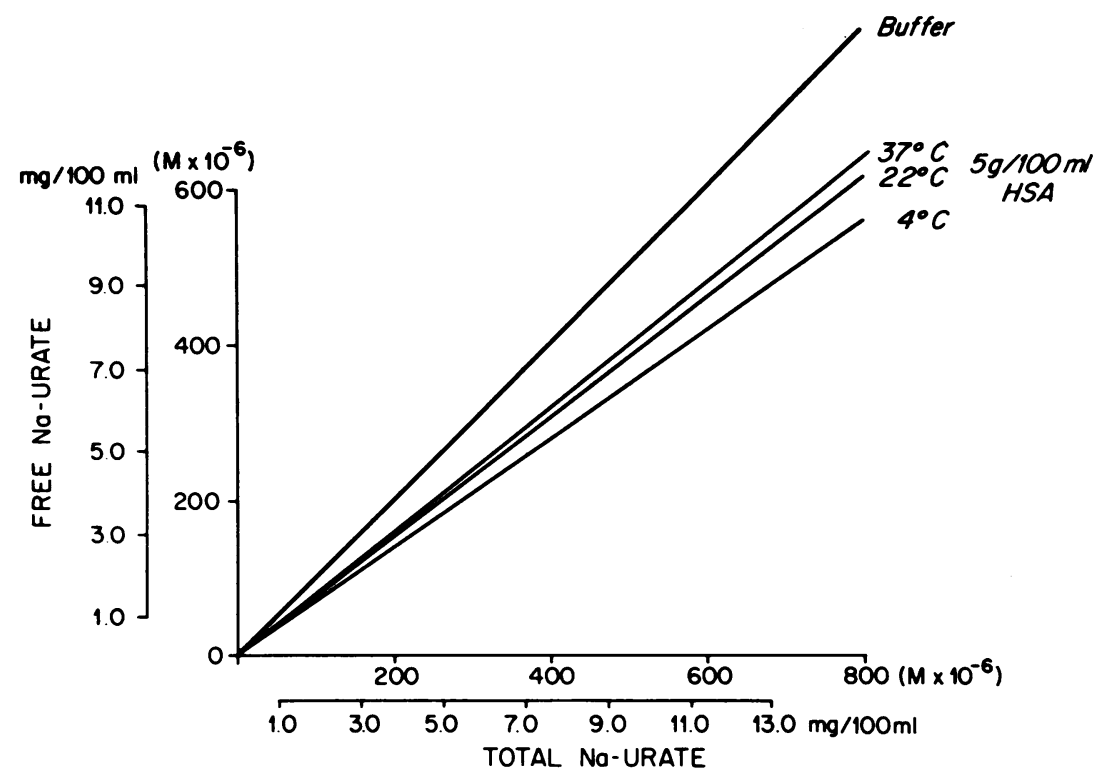

FIGURE 2 Effect of variation of temperature on Na-urate binding by $\mathrm{HSA}$ at $\mathrm{pH} 7.4$, ionic strength 0.16 . The buffer curve was identical at all three temperatures.

ultrafiltration proposed by Terepka, Chen, and Toribara (7).

At room temperature $\left(22.5^{\circ} \mathrm{C}\right)$ the percent of urate bound to $5 \mathrm{~g} / 100 \mathrm{ml} \mathrm{HSA}$ over the urate concentration range of $1.0-13.0 \mathrm{mg} / 100 \mathrm{ml}\left(52.6-683.8 \times 10^{-6} \mathrm{M}\right)$ was $22.6 \pm 0.3 \%$ (mean $\pm \mathrm{SE}$ ). This was constant over the whole range and is clearly demonstrated in Fig. 1, where three separate experiments with $5 \mathrm{~g} / 100 \mathrm{ml} \mathrm{HSA}$ are set out. The accuracy of the technique is shown by the very small scatter of the data. Fig. 2 demonstrates the effect of varying the temperature: mean urate bound was $30.3 \pm 0.6 \%$ at $4^{\circ} \mathrm{C}$ and $19.6 \pm 0.3 \%$ at $37^{\circ} \mathrm{C}$. At each temperature, free urate was linearly related to total urate $(r>0.99)$, and at all values of total urate the percent urate at any temperature was significantly different (regression analysis, $P<0.05$ ) from the percent bound at the other two temperatures. There was an almost linear decrease in binding when fraction bound was considered as a function of degrees Kelvin.

\section{DISCUSSION}

These studies clearly demonstrate that under physiologic in vitro conditions sodium urate is bound to HSA. The three properties of a solution that affect binding characteristics are $\mathrm{pH}$, ionic strength, and temperature. The choice of which buffer to use in determining binding characteristics is always difficult. Ideally, a bicarbonate/ carbon dioxide buffer system should be used (8) but is inconvenient. One of the advantages of using phosphate buffer is that the association constant of the phos- phate-albumin interaction is approximately $1.5 \times 10^{1} \mathrm{M}^{-1}$ (9), which is not significant when we consider the association constants of most anion interactions with albumin, and is less than a twentieth of the association constant calculated from these data for the urate-albumin interaction. The ionic strength of plasma is approximately 0.16 and was calculated in these experiments to be 0.158 . The reproducibility of this continuous ultrafiltration technique is shown in Fig. 1 where three separate runs of ultrafiltration with $5 \mathrm{~g} / 100 \mathrm{ml}$ of $\mathrm{HSA}$ in a chamber are set out. This and the ease with which binding over a large concentration range can be studied make this technique almost ideal for binding studies. However, in using this technique careful consideration must be given to the concept of altrafiltration (7) and the choice of membrane (10).

The fraction of sodium urate bound over the concentration range from 1 to $13 \mathrm{mg} / 100 \mathrm{ml}$ at any particular temperature was remarkably constant $(r>0.99)$. This would at first sight appear unusual, as in general the fractional binding of a ligand decreases as the ratio of ligand to protein increases, but, as Goldstein (11) demonstrated, fractional binding at very low concentrations of ligand may be constant. We are severely limited in the study of sodium urate binding by its insolubility and because a molar ratio of ligand to protein greater than 0.2 is difficult to achieve under physiological conditions. This value of the ratio of moles of sodium urate bound per mole of albumin at $10 \mathrm{mg} / 100 \mathrm{ml}$ total sodium urate is similar to that found by Alvsaker (1). The effect of an increase in temperature is clearly to reduce binding 
(Fig. 2) but at $37^{\circ} \mathrm{C}$ approximately $20 \%$ of the total urate is bound.

Within the range of urate concentration studied only a single class of binding site was detected. Although the range of concentration examined was too narrow to permit accurate calculation of the number of binding sites $(n)$ the value of the product of $n$ and the association constant, $n k$, was determined by extrapolation of a Goldstein plot of fraction-bound versus free urate to zero, when fraction bound $=\left[1+(k n \mathrm{P})^{-1}\right]^{-1}$. If $n$ is assumed equal to one then the association constant $k$ is $6.0 \times 10^{2} \mathrm{M}^{-1}\left(4^{\circ} \mathrm{C}\right), 4.47 \times 10^{2} \mathrm{M}^{-1}\left(22.5^{\circ} \mathrm{C}\right)$, and 3.88 $\times 10^{2} \mathrm{M}^{-1}\left(37^{\circ} \mathrm{C}\right)$. It is entirely possible that there are many weaker sites for the binding of urate with correspondingly lower $k$ value ( $n k$ is the experimentally determined constant), and the $k$ values given above are therefore maximum values. These, however, may be compared to those of other compounds where the $k$ values have been similarly determined on defatted HSA or defatted bovine serum albumin (BSA) (12). Salicylate (HSA) $k_{1}=1 \times 10^{5} \mathrm{M}^{-1}, k_{2}=5 \times 10^{3} \mathrm{M}^{-1}$, and $k_{3}=3 \times$ $10^{2} \mathrm{M}^{-1}$; phenylbutazone (BSA) $k_{1}=8 \times 10^{4} \mathrm{M}^{-1}, k_{2}=$ $1 \times 10^{3} \mathrm{M}^{-1}$, and $k_{3}=50 \mathrm{M}^{-1}$; and sulfadiazine (BSA) $k_{1}=7 \times 10^{3} \mathrm{M}^{-1}$. Clearly, these compounds could displace urate if binding sites are shared.

As filtration of sodium urate at the glomerulus is directly and continuously a function of the concentration of free urate in plasma. binding of urate to the degree found in this in vitro study will clearly have an effect on the renal handling of sodium urate. Moreover, displacement of bound urate by other drugs such as salicylate could conceivably induce uricosuria apart from any effect on the renal tubular handling of urate. Tissue deposition of urate might similarly be affected by the binding and displacement of urate.

These studies have established the basic properties of HSA-sodium urate interaction, and we can now examine the interaction of urate with albumin in the presence of competing drugs and the serum from patients with gout in order to determine whether their capacity to bind urate is normal.

\section{ACKNOWLEDGMENTS}

We are indebted to Mr. Robert Olsen for excellent technical assistance in the ultrafiltration experiments and to $\mathrm{Mr}$. J. Jacobson for urate analysis.

\section{REFERENCES}

1. Alvsaker, J. O. 1965. Uric acid in human plasma. III. Investigations on the interaction between the urate ion and human albumin. Scand. J. Clin. Lab. Invest. 17: 467.

2. Sheikh, M. I., and J. V. Møller. 1968. Binding of urate to proteins of human and rabbit plasma. Biochim. Biophys. Acta. $158: 456$.

3. Farrell, P. C., R. P. Popovich, and A. C. Babb. 1971. Binding levels of urate ions in human serum albumin and plasma. Biochim. Biophys. Acta. 243: 49.

4. Klinenberg, J. R., and I. Kippen. 1970. The binding of urate to plasma proteins determined by means of equilibrium dialysis. J. Lab. Clin. Med. 75: 503.

5. Blatt, W. F., S. M. Robinson, and H. J. Bixler. 1968. Membrane ultrafiltration: the diafiltration technique and its application to microsolute exchange and binding phenomena. Anal. Biochem. 26: 151.

6. Liddle, L., J. E. Seegmiller, and L. Laster. 1959. Enzymatic spectrophotometric method for determination of uric acid. J. Lab. Clin. Med. $54: 903$.

7. Terepka. A. R., P. S. Chen, Jr., and T. Y. Toribara. 1970. Ultrafiltration: a conceptual model and a study of sodium, potassium, chloride and water distribution in normal human sera. Physiol. Chem. Phys. 2: 59.

8. Campion, D. S., and J. D. K. North. 1965. Effect of protein binding of barbiturates on their rate of removal during peritoneal dialysis. J. Lab. Clin. Med. 66: 549.

9. Klotz, I. M., and J. M. Urquhart. 1949. The binding of organic ions by proteins. Buffer effects. J. Phys. Colloid Chem. 53: 100.

10. Heyde, E. 1973. Difficulties encountered with an ultrafiltration method for measuring the binding of ligands to protein. Anal. Biochem. 51: 61 .

11. Goldstein, A. 1949. The interactions of drugs and plasma proteins. Pharmacol. Rev. 1: 102.

12. Rudman, D., T. J. Bixler, II, and A. E. Del Rio. 1971. Effect of free fatty acids on binding of drugs by bovine serum albumin, by human serum albumin and by rabbit serum. J. Pharmacol. Exp. Ther. 176: 261. 